\title{
Process Standard in Curriculum 2013: An Analysis of Implementation
}

\author{
Dian Suciana Amri ${ }^{1 *}$, Marwan $^{2}$ \\ ${ }^{1,2}$ Universitas Negeri Padang, Padang, Indonesia \\ *Corresponding author. Email: diansuciana@gmail.com
}

\begin{abstract}
Education has an important role to increasing human resources, because quality of human resources is needed to face the increasing flow of globalization. One way to improve the quality of human resources is to improve the quality of education. One of the efforts made to improve the quality of education in Indonesia is by perfecting the educational curriculum. Currently the curriculum used is the curriculum 2013 revised edition which includes four changes from eight educational standards, one of which is the process standard. However, not all teachers can implement process standards properly in learning, so the authors are interested in conducting research that aims to reveal the implementation of the curriculum 2013 revised as well as the obstacles faced in high schools in Sungai Pagu District. The type of this research is descriptive research and the research subjects who serve as the main informants in this study are all economics teachers on Senior high school in Sungai Pagu district. Based on the results of the research that has been carried out, in general all economics teachers have prepared lesson plans and carried out learning in accordance with the rules of standard process of curriculum 2013 revised. However, there are still several indicators in the planning and implementation of learning that still need to be improved and completed. In the future, it is hoped that the implementation of education process standards will be more perfect so that the quality of education will also increase
\end{abstract}

Keywords: Process, Standard, Curriculum 2013.

\section{INTRODUCTION}

For companies, the existence of suppliers is as important as consumers. As an important part of Supply Chain Management (SCM), suppliers deserve the attention of management. [1] states that a good implementation of SCM can increase a competitiveness of the entire supply chain, Many studies also proved that a good implementation of SCM can improve companies' performances [2]-[5]. As part of the Management Control System (MCS), the effective SCM will enhance the supplier-buyer relationship. The longterm relationship can create a better trust and efficiencies.

Education has a very strategic role in improving the quality of human resources and efforts to realize the aspirations of the Indonesian nation to create general welfare and to educate the nation's life. Efforts to improve the quality of education in Indonesia have long been carried out by implementing various innovations in education. One of the efforts to improve the quality of education that has attracted the most attention is curriculum change. Curriculum means an educational program that contains various teaching materials and learning experiences that are programmed, planned and systematically designed on the basis of applicable norms and used as a guide in the learning process for educators to achieve educational goals [5]. Efforts to develop a dynamic educational curriculum are still being made so that it can achieve the educational goals set and can answer life's challenges that will come. Based on Law no. 20 of 2003 on curriculum, the curriculum development is carried out by referring to national education standards to achieve national education goals.

Related to efforts to improve the quality of education and realize the goals of national education, there has been a change in the curriculum from KTSP to the curriculum 2013 which has been implemented gradually since 2013. The curriculum 2013 contains four changes from the eight national education standards set by the government, namely graduate competency standards, content standards, process standards, and 
assessment standards. Process standards are very important educational standards because they relate to the learning process carried out by the teacher which will greatly affect students.

In fact, the teachers at some schools still have problems to implementing process standard of curriculum 2013 revised edition. This is due to the curriculum 2013 which is still in the refinement stage and is often revised in close proximity so that teachers feel confused about changes that occur quickly. There are still many teachers who experience problems in learning plan and learning implementation that accordance with the process standard of curriculum 2013 revised edition.

In learning plan, teachers still confuse and difficult to compiling lesson plans in accordance with the process standard rules. This is in accordance with the results of research conducted by [6] that in the implementation of the curriculum 2013, the teacher designed the lesson plan not yet referring to the 2013 curriculum rules. Meanwhile, in learning implementation, the teacher is still unable to apply the scientific approach maximally and not used the media in learning. In addition, based on research conducted by Ahmad (2014), the implementation of learning carried out by teachers is still not in accordance with the lesson plans that have been made for each meeting.

For this reason, a study was conducted on the implementation process standard of curriculum 2013 revised edition in economic subjects on senior high school in Sungai Pagu District South Solok Regency. The purpose of this study is to reveal the implementation of standard process of curriculum 2013 revised including planning and implementation of economic learning as well as the obstacles faced in implementing process standard of curriculum 2013 revised edition on all senior high schools in Sungai Pagu District, Solok Selatan Regency.

\section{METHOD}

In accordance with the problem formulation and research objectives that have been stated, this type of research is descriptive research. Descriptive research aims to describe or explain something as it is. Descriptive research is research conducted on independent variables, without making comparisons or connecting with other variables [9]. If viewed from the data analysis technique used, this study is a qualitative research.

This research was conducted in the even semester of the 2019/2020 school year on economics subjects on senior high schools in Sungai Pagu District, South Solok Regency, namely SMA Negeri 1 Solok Selatan and SMA Negeri 4 Solok Selatan. The research subjects who were used as the main informants in this study were all teachers of economics subjects in SMA Negeri 1 Solok Selatan and SMA Negeri 4 Solok Selatan. In addition, in this study, data collection was also carried out from the curriculum staff, school supervisors, and some students in social studies class X to class XII who were randomly selected from each school.

The data collection technique in this research is triangulation which is a combination of several data collection techniques, namely:

\section{Observation}

Observation technique is data collection by observing and recording phenomena that are systematically investigated [7] In this study, observations were made of the syllabus and lesson plans made by the economics teacher and the implementation of economic learning.

2. Interview

Interview is a conversation with a specific purpose carried out by two parties, namely the interviewer who asks the question and the interviewee who provides the answer to the question [8]. This study uses semi-structured interviews in the implementation of data collection in the field, on the grounds that this type of interview is included in the in-dept interview category, which in practice is freer when compared to structured interviews. This type of interview aims to find problems more openly so that researchers can add questions outside of the interview guidelines to reveal the opinions and ideas of the respondents. In this study, interviews were conducted about the planning and implementation of economic learning.

3. Documentation

Documentation is a qualitative data collection method by analyzing documents created by the subject himself or by others about the subject [8]. Documentation study is one way that researchers can get a picture from the subject's point of view through a written document and other documents written or made directly by the subject concerned. In this study, documentation of several school documents as well as syllabus and lesson plans were made by teachers of economic subjects.

The validity test of the data in this study using the credibility, transferability, dependability, and confirmability tests which can be described as follows:

1. Credibility Test

The credibility or trustworthiness of qualitative research data can be tested as follows:

a. Extension of Observations

Extension of observations means returning to the field to make observations or interviews again with data sources that have been encountered or new data sources. In this study, an extension of the observation was carried out to observe the learning process carried out by the teacher until credible data were obtained. 
b. Increase Persistence

Increasing persistence means making observations more carefully and continuously. Increasing persistence in this research is done by carefully analyzing the learning tools made by the teacher and observing carefully the teaching and learning activities carried out by teachers and students based on the observation guidelines that have been made.

c. Triangulation

Triangulation in credibility testing in this study is defined as checking data from various data collection techniques, namely by comparing the results of observations, interviews, and documentation

2. Transferability Test

The results of the research are said to meet the standards of transferability if the reader can get a clear picture of the results of the research. Therefore, research results need to be reported in a detailed, clear, systematic and reliable manner.

3. Dependability Test

Dependability testing is carried out to overcome miss conceptualization of research plans, data collection, interpretation of findings, and reporting of research results. Dependability testing is done by conducting an audit of the entire research process. The audit process is carried out by an independent auditor, namely the research supervisor.

4. Confirmability Test

Data confirmation or certainty is needed to determine whether the data obtained is objective or not. Testing confirmability means testing the results of the study in relation to the process being carried out. If the research results are a function of the research process that has been carried out, then the research has met the confirmability standard.

\section{RESULTS AND DISCUSSION}

\subsection{Learning Plan}

According to [10] learning plan is preparation for managing learning that will be carried out in the classroom to achieve goals. So that the learning objectives can be achieved properly, the teacher must make a good lesson plan as well. Learning plan includes the preparation of a syllabus and lesson plans that will guide future learning.

Based on the results of the study it can be said that the learning planning carried out by high school economics teachers in Sungai Pagu District is generally good and follows the rules regarding the process standard of curriculum 2013 revised, namely Permendikbud number 22 of 2016. From the results of the interviews conducted, it is known that all economic teachers already have and compile syllabus and lesson plans document at the beginning of the new school year and have been approved by the principal. The syllabus and lesson plans are prepared independently by teachers who are guided by the content standards and process standards in curriculum 2013 and follow the directions of the curriculum. However, some teachers admitted that they still had difficulties and were constrained in compiling the syllabus and lesson plans. Based on the results of observations or analysis of the contents of the syllabus documents compiled by high school economics teachers in Sungai Pagu District, it can be said that the teacher has made complete syllabus components consisting of subject identities, school identities, core competencies, basic competencies, subject matter, activities learning, assessment, time allocation, and learning resources. However, there are still some components that need to be fixed.

All of economics teachers on senior high schools in Sungai Pagu District have made their subject identities and school identities well in the syllabus. The formulation of core competencies and basic competencies in the observed syllabus all covered cognitive and psychomotor aspects. However, in the learning material section there are still teachers who only write material in general without classifying material in the form of facts, concepts, principles, and procedures, this is in line with the results of interviews with teachers who admit that they still have difficulty classifying material in the form of facts, concepts, principles, and procedures. Meanwhile, in the assessment section, all teachers have made an assessment that includes cognitive and psychomotor aspects. In addition, all economics teachers have also made allocations of time and relevant learning resources in the syllabus.

Meanwhile, based on observations or analysis of the contents of the lesson plans compiled by high school economics teachers in Sungai Pagu District, it can be said that all economic teachers have made complete lesson plans consisting of school identity, subject identity, class/semester, subject matter, allocation time, learning objectives, basic competencies and competency achievement indicators, learning materials, learning methods, learning media, learning resources, learning steps, and assessment. However, there are still some components that need to be fixed. In more detail it can be explained as follows:

a. Lesson plan's identity

All economics teachers have written down the complete RPP identity which includes the education unit, subject, class / semester, subject matter, and time allocation. This shows that teachers in economics have understood the importance of the identity of a document, making it easier to use.

b. Basic competencies and competency achievement indicator. 
The basic competency and competency achievement indicators have also been made well by the teacher which includes cognitive and psychomotor aspects and is arranged using measurable operational verbs.

c. Learning objectives

Learning objectives have been formulated based on basic competencies, but there are still teachers who are constrained in fulfilling the ABCD elements, namely audience, behavior, condition, and degree.

d. Learning materials

In the learning material, the teacher only writes an outline without specifying facts, concepts, principles, and procedures.

e. Learning methods

All teachers have also written the learning models, methods and approaches used in learning.

f. Media and learning resources

In making lesson plans, the economy teacher has written the media and learning resources that will be used in learning tailored to the learning objectives.

g. Learning activity steps

In the learning activity step section, all teachers have made preliminary, core, and closing activity steps. However, in core activities, some teachers have not made detailed syntax of the selected learning model but have described the syntax of the scientific approach used in learning.

h. Assessment of learning outcomes

In the assessment section contains assessment techniques, forms, and instruments which include an overview of affective, cognitive and psychomotor assessments. However, there is no attached question grid, questions, and assessment instruments that should be made by the teacher.

\subsection{Learning Implementation}

The implementation of learning is a teaching and learning process activity as a core element of learning activities which in its implementation is adjusted to the signs that have been prepared in the previous planning [1]. Meanwhile, the implementation of learning is a process that is arranged according to certain steps so that implementation achieves the expected results [12]. In order for the learning objectives to be achieved well, the implementation of learning must also be done properly according to the plan that has been made.

Based on the results of the research that has been carried out, in general all economics teachers have carried out learning in accordance with the process standard rules of the curriculum 2013 revised. However, there are several indicators of learning implementation that still need to be improved and completed. In detail, the implementation of learning carried out by economics teachers on senior high schools in Sungai Pagu District can be explained as follows:

a. Learning implementation requirements

From the results of the research conducted, it was obtained data that all of senior high schools in Sungai Pagu District had met the requirements for implementing learning, especially in economic subjects, namely:

1) One-hour class time is 45 minutes

2) The number of students per class is $20-36$ people,

3) The amount of text books is in accordance with the needs of students

b. Class management

Classroom management is an effort made by the person in charge of teaching and learning activities or helping with the intention of achieving optimal conditions so that teaching and learning activities can be carried out as expected [11]. In implementation learning, all economics teachers also carry out good classroom management. The teacher will make seating arrangements according to the characteristics of the lesson, at the beginning of the lesson the teacher arranges the seat classically and when discussing the seating arrangement is also adjusted. The teacher's voice intonation can be heard by all students and all teachers are dressed neatly and cleanly. The teacher has also tried to create orderly and comfortable learning, always pays attention to the safety of students, both neatness and comfort, if there are students who are a bit arguing, the teacher comes as a mediator. The teacher serves students who ask questions well and use polite language. In addition, the teacher also starts and ends learning according to the predetermined time.

c. Preliminary activities

In preliminary activities, the teacher tries to prepare students physically and psychologically so that they are ready and able to concentrate on taking part in learning. At the beginning of the lesson, the teacher greets students with enthusiastic and happy tones by saying greetings and checking the attendance of students. All economics teachers also explain the learning objectives and competencies to be achieved and provide an outline of the scope of material and plans for learning activities. However, some teachers do not motivate students and do not link previous knowledge with the material to be studied.

d. Core activities

In the implementation of core activities, all economics teachers can master the material being taught well, the material is also in accordance with the objectives of the lesson and is taught systematically from easy to difficult. However, some teachers have not linked this material to the 
development of science and technology. All economics teachers have also applied a scientific approach to learning by facilitating students to observe, ask, try, reason, and communicate. However, the observing activities carried out by the teacher were different from what was written in the lesson plans. Likewise, the application of the learning model is also not in accordance with what is written in the lesson plan. Based on the results of interviews, it was also known that economics teachers sometimes still use the lecture method in learning. All economics teachers have also used varied and relevant learning resources for learning objectives, namely from economics textbooks and the internet, students who have cellphones are welcome to search for material using the internet. However, economics teachers still do not use varied media in learning. This is in accordance with the results of interviews with curriculum staff and supervisors that the level of media use by teachers in learning is still low.

e. Closing activities

The closing activities in the learning carried out by all economics teachers is generally considered good and in accordance with the process standard rules for the curriculum 2013 revised. In the closing activity, the teacher guides students to make conclusions on the material that has been studied, follows up in the form of giving homework, and submits activity plans at the next meeting. However, there are still some teachers who do not provide feedback on the learning being carried out.

\subsection{Constraints faced}

Based on the results of research that has been carried out on the implementation of process standard of the curriculum 2013 revised edition which includes planning and implementing learning on high school economics teachers in Sungai Pagu district still have several obstacles, namely as follows:

a. Learning plan

1) Teachers still have difficulty in determining factual, conceptual, and procedural material

2) The teacher is still hesitant in designing learning objectives that meet the ABCD elements (audience, behavior, conditional, degree)

3) Teachers still have difficulty in designing instructional media

4) The teacher is still confused about determining the right learning model and the steps or syntax of the learning model

5) There are still many teachers who do not make assessment attachments in lesson plan like as the grid questions, questions and answer keys, as well as assessment instruments

6) Teachers need a long time in making lesson plans, especially for teachers whose mastery of IT is still low

b. Learning implementation

1) The teacher still has not used varied media in learning. This is because there are still teachers who have difficulty making media due to their low IT mastery. In addition, the means of supporting the use of media such as LCD projectors provided by schools can only be used interchangeably.

2) The teacher has not used a varied learning model because the teacher still has difficulty in determining the appropriate learning model according to the material and lesson objectives and does not understand the syntax or steps of the learning model in the curriculum 2013.

3) Teachers sometimes still use the lecture method in learning because many students are deemed unable to carry out the curriculum 2013 learning properly. There are still students who have difficulty collecting and processing the material, some students are also still ashamed to express their opinions in the discussion, sometimes the discussion material deviates from the material being studied, and the time needed for discussion is long enough so that the learning objectives are not properly achieved.

4) Sometimes the teacher cannot do the closing activities well because much of the learning time is spent doing core activities.

5) Sometimes the implementation of learning carried out by the teacher is not in accordance with what is written in the lesson plan.

\section{CONCLUSION}

Based on the results of research about the implementation of the standard process of curriculum 2013 revised edition for economic subjects on senior high schools in Sungai Pagu District, can be concluded as follows:

a. The learning plan made by economics teachers on senior high schools in Sungai Pagu District is generally good in accordance with the process standard rules of the curriculum 2013 revised, namely Permendikbud number 22 of 2016. All teachers have syllabus and lesson plans at the beginning of the new school year. The contents of the lesson plan document prepared by the economics teacher have fulfilled $88 \%-94 \%$ of all components of arranging lesson plan in accordance with the standard process rules of curriculum 2013 revised. Some components that still need to be improved and completed are in the section on 
learning objectives, learning materials, learning methods, steps for learning activities, and lesson plans attachments.

b. The implementation of learning carried out by economics teachers on senior high schools in Sungai Pagu District is generally good in accordance with the standard process rules of curriculum 2013 revised, namely Permendikbud number 22 of 2016. From the observations it can be seen that the implementation of the learning carried out has met $82 \%-91 \%$ of the learning implementation criteria are accordance with the standard process of curriculum 2013. All the requirements for implementing learning are well fulfilled, as well as classroom management that teachers can do well too. Part of the implementation of learning that still has to improve is designing and using learning media, and implementing learning models and methods.

\section{ACKNOWLEDGMENTS}

The process of completing this thesis is of course inseparable from the assistance, guidance, motivation, prayers and directions given by various parties, both morally and materially, and given either directly or indirectly. For that, on this occasion with all humility the author would like to sincerely thank to Dr. Marwan, S.Pd, M.Si as the supervisor who always takes the time to provide guidance, direction, and motivation from the beginning to the end of this thesis writing. In addition, the author would also like to thank the honorable ones:

1. Mr Dr. Idris, M.Si as Dean of the Faculty of Economics, UNP for the facilities that have been provided.

2. Mrs. Dr. Susi Evanita, M.S as the Head of the Master of Economic Education Study Program for all the facilities and support.

3. All teaching staff and administrative staff of the Master Economic Education in Padang State University

4. School supervisor, headmasters, teachers, administrative staff, and students of senior high school in Sungai Pagu district

\section{REFERENCES}

[1] A. Majid, "Learning Strategy". Bandung: PT Remaja Rosdakarya, 2014

[2] Ahmad, "Understanding the 2013 Curriculum of English Teaching through the Teachers and Policymakers Perspectives. "International Journal of Enhanced Research in Educational Development (IJERED), Vol. 2(4), pp 6-15, 2014.

[3] A. Sudijono, "Intoduction of Educational Evaluation", Jakarta: PT. Raja Grafindo, 2017

[4] A. Shoimin, "68 Innovative Learning Models in Curricullum 2013". Yogyakarta: Ar-ruz Media, 2014.
[5] Dakir, "Planning and Development of Curriculum", Jakarta: PT Rineka Cipta, 2004.

[6] Gunawan, "Indonesian Curriculum 2013: Instructional Management, Obstacles Faced by Teachers in Implementation and the Way Forward," Journal Advances in Social Science, Education and Humanities Research, Vol. 128(3), pp 56-63, 2017.

[7] H. Sutrisno, "Metodologi Research", Jakarta: Rineka Cipta, 1987.

[8] H. Herdiansyah, "Qualitative Research Methods for Social Sciences", Jakarta: Salemba Humanika, 2010.

[9] Sugiyono, "Educational Research Methods", Bandung: Alfabeta, 2018

[10] L. Hakim, Learning Plan, Jakarta: CV. Wacana Prima, 2009.

[11] Djamarah, "Teaching and Learning Strategy", Jakarta: Rineka Cipta, 2013.

[12] N. Sudjana, Coaching and Development of Curricullum in The Schools, Bandung: Sinar Baru Algesindo, 2004 